\title{
DEVELOPMENT OF CONCEPTUAL BASES OF THE EMPLOYEE LIFE CYCLE WITHIN AN ORGANIZATION
}

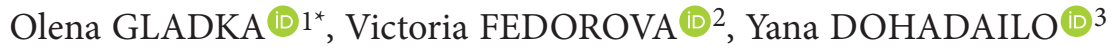 \\ ${ }^{1}$ Independent researcher, Ottawa, Canada \\ ${ }^{2}$ Department of Economics and Entrepreneurship, Kharkiv National Automobile and Highway University, \\ Kharkiv, Ukraine \\ ${ }^{3}$ Department of Management, Kharkiv National Automobile and Highway University, Kharkiv, Ukraine
}

Received 7 September 2020; accepted 22 August 2021

\begin{abstract}
The purpose of the study is to review and integrate various definitions of the employee life cycle (ELC) and to develop new conceptual bases of ELC by applying logical analysis and systemic approach. In this article, we suggest the employee life cycle has a "client-based" approach. Therefore the development of the ELC is similar to the development of the client life cycle and each stage of this process requires adoption and use of external and internal personnel marketing tools. At the same time, it implies simultaneous various activities of employees and employers alike. A customer-centric process on the labor markets (external and internal) is initiated by the personnel marketing product. It is defined by three levels aiming to attract and retain employees. The model of the ELC proposed hereafter shows the bilateral mechanism of the employee-employer interaction. Through the activities of external (employee attraction) or internal (employee retention) personnel marketing the organization can build its "perceived" or "received" Employer Value Proposition (EVP). The refined definition of the ELC is based on the theoretical foundations of personnel marketing and takes into account the employee and the employer's perspectives; our definition identifies the ELC time frame and defines indicators of the ELC measurement for further empirical studies. Suggested ELC stages were developed in a way to reflect characteristics and actions for the employer and the employee simultaneously. To maintain or renew the employee engagement level a set of measures were suggested for implementation at each stage of the ELC.
\end{abstract}

Keywords: employee life cycle, employee-employer interaction, ELC model, personnel marketing, employee engagement.

JEL Classification: J2, M1, M31, M5.

\section{Introduction}

Under the modern market conditions, when the economy is largely based on innovation, learning, and knowledge of employees, the main source of competitive advantage of any organization is the qualified and committed human resources. Every organization faces a very crucial challenge consisting not only in attracting talented employees but also in retaining them for a longer period. Effective management of processes related to employees' attraction, recruitment, development, and retention entirely depend on the effective management of the ELC within an organization. The ELC has been a focus of attention in the recent academic and professional literature (Smither, 2003; Tabassum \& Sahni, 2017; Shyam \& Ramachandra Gowda, 2015; Verive \& DeLay, 2006; Lavelle, 2007; Costello, 2006; Thompsen, 2010; Farnan et al., 2010; Saltmarsh, 2017; Welty, 2009; Rouse, 2019; Burke, 2019; Eaton Gaul, 2019;
Leung, 2018; Gutierrez, 2017; Lowenstein, 2017; Biasi, 2017; Lawrence, 2017; Sato et al., 2019).

Many studies show that the cost of replacement of skillful employees is much higher than the cost of retention. According to the statistical data analysis of the Retention Report of The Work Institute (2019), 41.4 million U.S. employees voluntarily left their jobs; that is to say, more than 27 out of every 100 U.S. employees quit in 2018. The cost to lose a U.S. employees is 15,000 USD. Also, according to this report, it is considered that small investments in employee retention can significantly reduce the direct costs of employee turnover.

Collected data shows that among the main reasons of leaving were the following: career development (22.2\%), work-life balance (12\%), managers' behaviour (11.3\%), relocation (10.2\%), compensation and benefits (9.6\%), well-being (8.4\%), job characteristics $(8.1 \%)$, involuntary

*Corresponding author. E-mail: olena.gladka@gmail.com 
(6.7\%), retirement $(6.3 \%)$ and work environment $(5.2 \%)$. The Work Institute employee turnover themes are categorized as more or less preventable. The interesting fact the Institute found is that $76.8 \%$ of turnover was more preventable as compared to $23.2 \%$ that was less preventable.

The research of Moynihan and Landuyt (2008) identifies possible reasons for employee turnover in the public sector. The authors hypothesized a set of variables that might have the most significant impact on employee turnover. The results have shown that the turnover may depend on employees': stability in life (employees who have reached certain stability in their life, and who have financial and family obligations are less likely to look for a new job); age (employees who are over the age of 30 are 5.3 percentage points less likely to quit than employees under the age of 30); gender (women are significantly less likely to quit than their male counterparts); education (employees with a college degree or higher were 5 percentage points more likely to leave than those with lower educational attainment), etc. On the one hand, the research revealed quite obvious factors significantly related to the turnover, such as job satisfaction and fair pay. An interesting finding was the area of diversity, where according to the authors, "HRM policies can have a positive impact on ensuring a diverse workforce, which in turn reduces turnover" (Moynihan \& Landuyt, 2008).

From the diversity perspective, the employee life cycle may vary depending on the employee's generation, education, gender, etc. The U.S. Bureau of Labour Statistics (Bureau of Labour Statistics, 2018) reports that in January 2018, median employee tenure for men was 4.3 years; while the median tenure for women was 4.0 years. Generally, median employee tenure was higher among older employees than younger ones. For example, the median tenure of employees ages 55 to 64 (10.1 years) was more than three times that of employees ages 25 to 34 (2.8 years). Also, a larger proportion of older employees than younger employees had 10 years or more of tenure. For example, $57 \%$ of employees ages 60 to 64 were employed for at least 10 years with their current employer in January 2018, compared with $12 \%$ of those ages 30 to 34 .

The foregoing indicates that the ability to effectively manage ELC can become a key asset not only in attracting the best specialists but also in retaining them within an organization and in preventing costs related to the employees' turnover. Employee life cycle management also becomes a crucial topic when it comes to diversity management.

It would be reasonable enough to say that each employee has specific time frames of their career life cycle and its stages. Every employee is unique, and when joining an organization they bring a unique set of skills, knowledge and talents, cultural backgrounds, career history, life experiences, and wisdom. Additionally, each one has own career aspirations, expectations, and the level of requirements towards the potential or current workplace and its characteristics. All the above-mentioned combined may result in a unique employee life cycle length. In practice it may look like that: some new employees require more functional training at the beginning and become quickly operational and effective in the team; while others need a more individual approach and dig into specific job details and therefore, they need more time before they can work at the same level of professionalism as other team members.

For instance, Lavelle (2007) suggested that the employment life cycles may be different depending on the impact of employees' talents on the business versus their scarcity/cost. The architecture model analyzed by the author combines the career lifecycle-workplace results in the different employee life cycles, as well as in different numbers of life cycle stages and their various lengths (Lavelle, 2007). Hence, it is crucial for an employer not only to know which stage of the life cycle employees are going through but also to timely react when needed to prevent loss of talents.

Despite the importance of the notion of the employee life cycle and its management, the concept remains underexplored $^{1}$. Therefore, based on the review of existing literature the purpose of this article is threefold. Firstly, we seek to develop the employee life cycle conceptual bases. Secondly, we analyze the essence of existing definitions related to the ELC and clarify the definition of "the employee life cycle within an organization". Thirdly, we suggest a new model of ELC and determine the titles and characteristics of the ELC stages.

\section{Literature overview}

Michael Beer, Bert Spector, and Paul R. Lawrence were the first authors (Walker, 1980) who described the ELC stages in 1984 in their work "Managing human assets" (Beer et al., 1984). They considered three main HR flows: inflow, internal flow and outflow. All together they form a sequence of $8 \mathrm{HR}$ processes, which today can be referred to as the ELC career stages: recruitment; assessment and selection; orientation and socialization; evaluation of performance and potential; career development; internal placement, promotion, and demotion; education and training; termination, outplacement, and retirement. The forth flow represents a mixture of the three main ones. As suggested by the authors, the existing flows could result in 4 diverse life cycles, or so-called patterns: lifelong employment system, up-or-out system, unstable in-and-out system and mixed patterns (Beer et al., 1984). Since then the employee life cycle theory has evolved and today authors give different definitions to the employee life cycle and identify different stages.

In our literature review, we take into account academic research results and professional HR publications

1 Due to the lack of sufficient research papers dedicated to the specific area of ELC, the literature review was made based on the available trusted papers in the explored databases; consulting papers complemented the resources list. 
since this topic has evolved not only in theory but mainly in practice. Our literature review shows a variety of definitions of the "employee life cycle within an organization". First of all, these definitions are different in terms of meaning. Second of all, different categories are used to interpret the essence of these definitions (see Table 1). There is no consensus among researchers not only regarding the essence of the phenomenon but neither the terminology describing it. Most often authors use such terms as: "the employee life cycle" (Smither, 2003; Tabassum \& Sahni, 2017; Shyam \& Ramachandra Gowda, 2015; Verive \& DeLay, 2006; Costello, 2006; Farnan et al., 2010; Rouse, 2019; Cattermole, 2019; Eaton Gaul, 2019; Leung, 2018; Gutierrez, 2017; Lowenstein, 2017; Biasi, 2017; Lawrence, 2017). Others use "the employment life cycle" (Lavelle, 2007; Saltmarsh, 2017; Welty, 2009) or "the human capital cycle" (Thompsen, 2010). The following table summarizes the definitions we find in the literature.

Table 1. Analysis of terms used by researchers

\begin{tabular}{|c|c|c|c|}
\hline \multirow[b]{2}{*}{ Author } & \multicolumn{3}{|c|}{ Used terms } \\
\hline & $\begin{array}{l}\text { the emp- } \\
\text { loyee life } \\
\text { cycle }\end{array}$ & $\begin{array}{l}\text { the emp- } \\
\text { loyment } \\
\text { lifecycle }\end{array}$ & $\begin{array}{l}\text { the human } \\
\text { capital cycle }\end{array}$ \\
\hline Smither, 2003 & + & & \\
\hline $\begin{array}{l}\text { Tabassum \& } \\
\text { Sahni, } 2017\end{array}$ & + & & \\
\hline $\begin{array}{l}\text { Shyam \& } \\
\text { Ramachandra } \\
\text { Gowda, } 2015\end{array}$ & + & & \\
\hline $\begin{array}{l}\text { Verive \& DeLay, } \\
2006\end{array}$ & + & & \\
\hline Lavelle, 2007 & & + & \\
\hline Costello, 2006 & + & & \\
\hline Thompsen, 2010 & & & + \\
\hline $\begin{array}{l}\text { Farnan et al., } \\
2010\end{array}$ & + & & \\
\hline Saltmarsh, 2017 & & + & \\
\hline Welty, 2009 & & + & \\
\hline Rouse, 2019 & + & & \\
\hline Cattermole, 2019 & + & & \\
\hline $\begin{array}{l}\text { Eaton Gaul, } \\
2019\end{array}$ & + & & \\
\hline Leung, 2018 & + & & \\
\hline Gutierrez, 2017 & + & & \\
\hline $\begin{array}{l}\text { Lowenstein, } \\
2017\end{array}$ & + & & \\
\hline Biasi, 2017 & + & & \\
\hline Lawrence, 2017 & + & & \\
\hline Sato et al., 2019 & + & & \\
\hline
\end{tabular}

The use of different terms had to be analyzed. For instance, according to the English Dictionary, "the $h u$ man capital - is the skills, knowledge, and experience possessed by an individual or population, viewed in terms of their value or cost to an organization or country" (Cambridge Dictionary, 2019). So, speaking about human capital within one organization, the term "human capital cycle" may characterize changes in time of all accumulated knowledge, skills, and experience of its personnel (including those who have already left the organization). At the country level the "human capital cycle" can be measured by all accumulated knowledge, skills and experience of the economically active population at a given moment, as well as those of the previous and the future generations.

The term of "employment" is defined as "the work that you are paid to do for a particular company or organization" (Cambridge Dictionary, 2019), or "employment - is the number of people who have jobs, or the ability to provide jobs to other people (Cambridge Dictionary, 2019). So, this might mean that the employment life cycle represents the relationship between employee and employer. However, the starting point for them should be the moment when an employee begins to perform a job for an employer. This excludes the possibility to represent a broader version of the life cycle and includes pre-work stages, such as attraction, selection, recruitment, and hiring.

The term "employee life cycle" is the most commonly used one. It refers to one individual and may include not only their knowledge, skills and experience, but also motivation and dedication to work for a specific organization. Thus this highlights a need of applying individualized methods and tools for employee's management within an organization in contrast with commonly used standartized methods and tools.

Previous researches (Smither, 2003; Tabassum \& Sahni, 2017; Shyam \& Ramachandra Gowda, 2015; Verive \& DeLay, 2006; Lavelle, 2007; Costello, 2006; Thompsen, 2010; Farnan et al., 2010; Saltmarsh, 2017; Welty, 2009; Rouse, 2019; Burke, 2019; Eaton Gaul, 2019; Leung, 2018; Gutierrez, 2017; Lowenstein, 2017; Biasi, 2017; Lawrence, 2017) suggested different ELC definitions, presented in Table 2.

The ELC main characteristics/features were summarized in Table 3.

Analysis of the content of Tables 2 and 3 shows a lack of consistency among definitions of the employee life cycle. The life cycle stages are also different in name, number and length. Given these differences of opinions, in the following paragraphs we will try to answer the next 4 questions:

- Question 1: What does the ELC within an organization represent - a concept, a model, a method, a way, a progression, or a process?

- Question 2: Does the ELC have a "product-based" or a "client-based" approach?

- Question 3: What does the ELC start from?

- Question 4: Should the ELC be described from the perspective of an employer or an employee? 
Table 2. Definitions of the "employee life cycle within an organization" and stages

\begin{tabular}{|c|c|c|}
\hline Author & Definition provided & Names of life cycle stages \\
\hline Smither, 2003 & - & $\begin{array}{l}\text { 1. Introduction Phase; } \\
\text { 2. Growth Phase; } \\
\text { 3. Maturity Phase; } \\
\text { 4. Decline Phase }\end{array}$ \\
\hline $\begin{array}{l}\text { Tabassum \& } \\
\text { Sahni, } \\
2017\end{array}$ & $\begin{array}{l}\text { "the method that the employees undergo from the time, when they } \\
\text { enter a company till they leave", 2017, p. } 5445\end{array}$ & $\begin{array}{l}\text { 1. Recruitment and Selection; } \\
\text { 2. Employee Contract; } \\
\text { 3. Personal Development Program; } \\
\text { 4. Annual Compensation; } \\
\text { 5. Termination of Employment }\end{array}$ \\
\hline $\begin{array}{l}\text { Shyam \& } \\
\text { Ramachandra } \\
\text { Gowda, } 2015\end{array}$ & $\begin{array}{l}\text { "a concept in human resource management that describes the stages of } \\
\text { an employee's time with a particular company and the role the human } \\
\text { resources department plays at each stage", } 2015, \text { p. } 21\end{array}$ & $\begin{array}{l}\text { 1. Introduction; } \\
\text { 2. Development; } \\
\text { 3. Promotion; } \\
\text { 4. Mid-Career Crisis/Retirement }\end{array}$ \\
\hline $\begin{array}{l}\text { Verive \& } \\
\text { DeLay, } \\
2006\end{array}$ & - & $\begin{array}{l}\text { 1. Attract; } \\
\text { 2. Join; } \\
\text { 3. Engage; } \\
\text { 4. Leave }\end{array}$ \\
\hline $\begin{array}{l}\text { Lavelle, } \\
2007\end{array}$ & $\begin{array}{l}\text { "the fusion of the employment value proposition and corresponding } \\
\text { employment relationship creates the employment lifecycle, a versatile } \\
\text { model that is capable of playing several key roles in the manpower } \\
\text { planning process", } 2007, \text { p. } 377\end{array}$ & $\begin{array}{l}\text { 1. Joining; } \\
\text { 2. Committing; } \\
\text { 3. Contributing and Growing; } \\
\text { 4. Choosing; } \\
\text { 5. Plateauing; } \\
\text { 6. Passing on; } \\
\text { 7. Wisdom }\end{array}$ \\
\hline Costello, 2006 & - & $\begin{array}{l}\text { 1. Selection and hiring; } \\
\text { 2. New hire development; } \\
\text { 3. Ongoing performance management; } \\
\text { 4. Career development }\end{array}$ \\
\hline $\begin{array}{l}\text { Thompsen, } \\
2010\end{array}$ & $\begin{array}{l}\text { "a practical model that encompasses a range of strategic and tactical } \\
\text { considerations required to more fully address core business issues } \\
\text { and effects on all three elements to company success: customers, } \\
\text { organizations, and their employees (or what we call the Triple Win)", } \\
2010 \text {, p. } 15\end{array}$ & $\begin{array}{l}\text { 1. Emergence of new need/or a new } \\
\text { business strategy; } \\
\text { 2. Definition of Human Capital Plan; } \\
\text { 3. Recruitment and selection; } \\
\text { 4. Employee On-Boarding and } \\
\text { Orientation; } \\
\text { 5. Development of Ongoing Capabilities } \\
\text { or Career Growth; } \\
\text { 6. Employee Departure }\end{array}$ \\
\hline $\begin{array}{l}\text { Farnan et al., } \\
2010\end{array}$ & $\begin{array}{l}\text { "the model is implemented through five components: } \\
\text { 1. Recruiting: Hire the best, by using consistency and rigor in the } \\
\text { hiring process. } \\
\text { 2. On-boarding: Ensure new hire retention through comprehensive } \\
\text { assimilation actions. } \\
\text { 3. Managing performance: Strive for high performance by providing } \\
\text { timely and frequent feedback to each employee. } \\
\text { 4. Rewarding performance: Pay for performance, differentiate } \\
\text { performance, and recognize and reward top performance. } \\
\text { 5. Developing talent: Foster continuous improvement by providing } \\
\text { training opportunities for each employee to grow professionally", 2010, } \\
\text { p. } 4\end{array}$ & $\begin{array}{l}\text { 1. Recruiting; } \\
\text { 2. On-Boarding; } \\
\text { 3. Rewarding Performance; } \\
\text { 4. Managing Performance; } \\
\text { 5. Developing Talent }\end{array}$ \\
\hline $\begin{array}{l}\text { Saltmarsh, } \\
2017\end{array}$ & $\begin{array}{l}\text { "The employment cycle involves the stages employees go through and } \\
\text { the role HR or similar support takes on during those stages", 2007, p. } 8\end{array}$ & $\begin{array}{l}\text { 1. Recruitment; } \\
\text { 2. Education; } \\
\text { 3. Motivation; } \\
\text { 4. Evaluation; } \\
\text { 5. Celebration }\end{array}$ \\
\hline $\begin{array}{l}\text { Welty, } \\
2009\end{array}$ & - & $\begin{array}{l}\text { 1. Advertising the position; } \\
\text { 2. Recruiting; } \\
\text { 3. Selection; } \\
\text { 4. Hiring; } \\
\text { 5. New employee orientation; } \\
\text { 6. Probation; } \\
\text { 7. Training and development; } \\
\text { 8. Performance review; }\end{array}$ \\
\hline
\end{tabular}


End of Table 2

\begin{tabular}{|c|c|c|}
\hline Author & Definition provided & Names of life cycle stages \\
\hline & & $\begin{array}{l}\text { 9. Promotion; } \\
\text { 10. Coaching and disciplining; } \\
\text { 11. Separation; } \\
\text { 12. Benefit entitlements }\end{array}$ \\
\hline $\begin{array}{l}\text { Rouse, } \\
2019\end{array}$ & $\begin{array}{l}\text { "an HR model that identifies the different stages a worker advances } \\
\text { through in an organization and the role HR plays in optimizing that } \\
\text { progress", } 2019\end{array}$ & $\begin{array}{l}\text { 1. Recruit; } \\
\text { 2. Onboard; } \\
\text { 3. Develop; } \\
\text { 4. Retain; } \\
\text { 5. Off-board }\end{array}$ \\
\hline $\begin{array}{l}\text { Burke, } \\
2019\end{array}$ & $\begin{array}{l}\text { "a way to visualise employee's and how they engage with organisation", } \\
2019\end{array}$ & $\begin{array}{l}\text { 1. Attraction; } \\
\text { 2. Recruitment; } \\
\text { 3. Onboarding; } \\
\text { 4. Development; } \\
\text { 5. Retention; } \\
\text { 6. Separation }\end{array}$ \\
\hline $\begin{array}{l}\text { Cattermole, } \\
2019\end{array}$ & - & $\begin{array}{l}\text { 1. Attraction; } \\
\text { 2. Recruitment; } \\
\text { 3. Onboarding; } \\
\text { 4. Development; } \\
\text { 5. Retention; } \\
\text { 6. Separation }\end{array}$ \\
\hline $\begin{array}{l}\text { Eaton Gaul, } \\
2019\end{array}$ & - & $\begin{array}{l}\text { 1. Attraction; } \\
\text { 2. Recruitment; } \\
\text { 3. Onboarding, learning and } \\
\text { development; } \\
\text { 4. Retention; } \\
\text { 5. Re-recruiting and role reengineering; } \\
\text { 6. Separation }\end{array}$ \\
\hline $\begin{array}{l}\text { Leung, } \\
2018\end{array}$ & $\begin{array}{l}\text { "a natural progression of phases in the way an employee interacts with } \\
\text { your organization", } 2018\end{array}$ & $\begin{array}{l}\text { 1. Attraction; } \\
\text { 2. Recruitment; } \\
\text { 3. Onboarding; } \\
\text { 4. Development; } \\
\text { 5. Retention; } \\
\text { 6. Separation }\end{array}$ \\
\hline $\begin{array}{l}\text { Gutierrez, } \\
2017\end{array}$ & $\begin{array}{l}\text { "an ongoing process that starts and ends with competent employees in } \\
\text { your organization", } 2017\end{array}$ & $\begin{array}{l}\text { 1. Outreach \& Pre-Employment; } \\
\text { 2. Recruitment; } \\
\text { 3. On-Boarding; } \\
\text { 4. Performance Management; } \\
\text { 5. Training \& Development; } \\
\text { 6. Off-boarding }\end{array}$ \\
\hline $\begin{array}{l}\text { Lowenstein, } \\
2017\end{array}$ & $\begin{array}{l}\text { "an HR-based model that identifies stages in employees' careers to help } \\
\text { guide their management and optimize associated processes", } 2017\end{array}$ & $\begin{array}{l}\text { 1. Recruitment; } \\
\text { 2. Onboarding; } \\
\text { 3. Career Planning; } \\
\text { 4. Career Development; } \\
\text { 5. Termination }\end{array}$ \\
\hline $\begin{array}{l}\text { Biasi, } \\
2017\end{array}$ & $\begin{array}{l}\text { "a method to visualize how the employee engages with the organization } \\
\text { they are a part of", } 2017\end{array}$ & $\begin{array}{l}\text { 1. Recruitment; } \\
\text { 2. Onboarding; } \\
\text { 3. Development; } \\
\text { 4. Retention; } \\
\text { 5. Exit or Separation }\end{array}$ \\
\hline $\begin{array}{l}\text { Lawrence, } \\
2017\end{array}$ & - & $\begin{array}{l}\text { 1. Recruitment; } \\
\text { 2. Development; } \\
\text { 3. Utility } \\
\text { 4. Progression; } \\
\text { 5. Exit }\end{array}$ \\
\hline $\begin{array}{l}\text { Sato et al., } \\
2019\end{array}$ & - & $\begin{array}{l}\text { 1. Concept } \\
\text { 2. Development } \\
\text { 3. Production } \\
\text { 4. Utilization/Support } \\
\text { 5. Retirement }\end{array}$ \\
\hline
\end{tabular}


Table 3. Analysis of the notion "employee lifecycle within an organization"

\begin{tabular}{|c|c|c|c|c|c|c|c|c|c|c|c|c|c|c|}
\hline \multirow[b]{2}{*}{ Main characteristics } & \multicolumn{14}{|c|}{ Authors } \\
\hline & 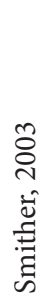 & 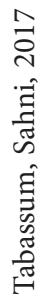 & 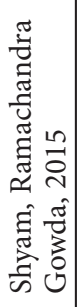 & 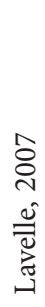 & 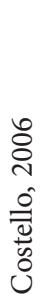 & 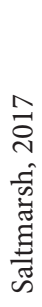 & 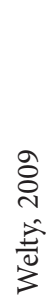 & 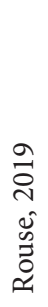 & 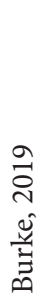 & 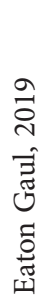 & 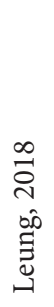 & 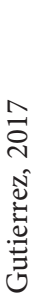 & 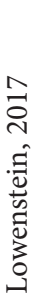 & 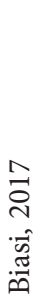 \\
\hline 1. It is comparable to the product life cycle & + & + & + & & & & & & & & & & & \\
\hline $\begin{array}{l}\text { 2. It is comparable to the customer } \\
\text { lifecycle }\end{array}$ & & & & & & & & & & & & & + & \\
\hline $\begin{array}{l}\text { 3. Duration of the life cycle and its } \\
\text { stages depends both on the employee } \\
\text { characteristics and on the activities of the } \\
\text { employer }\end{array}$ & + & + & & & & & & & & & & & & \\
\hline $\begin{array}{l}\text { 4. At every stage each employee have } \\
\text { different needs and expectations }\end{array}$ & + & & & + & & + & & + & & & & + & & \\
\hline $\begin{array}{l}\text { 5. It reflects the interaction between an } \\
\text { employee and an employer }\end{array}$ & & & & & & & & & + & & + & & & + \\
\hline $\begin{array}{l}\text { 6. It requires different management } \\
\text { methods at each stage and the } \\
\text { development of individual strategies }\end{array}$ & + & & & + & + & + & & + & & & & + & & + \\
\hline $\begin{array}{l}\text { 7. It describes the career stages of an } \\
\text { employee within an organization }\end{array}$ & & & + & & + & & & & & + & & & & \\
\hline
\end{tabular}

\section{Results of the study}

\subsection{What does the ELC within an organization represent?}

In the Oxford Advanced Learner's Dictionary the "life cycle" is interpreted as "the period of time during which something, for example, a product, is developed and used". Thus, the life cycle is understood as a certain period during which a researched object is created (born) and used until its liquidation (death). Therefore, it will be logical to argue that the "employee life cycle", (the object) can be seen as a period when the relationship between an employee and an employer is developed, i.e. the time of employee-employer interaction (period of time of employment relationships). Lavelle (2007) expressed the similar opinion - "it remains true that employment continues to be relationship-based and, arguably, the central HR challenge remains that of supporting organizational and staff efforts to make employment relationships work in a mutually satisfactory fashion" (Lavelle, 2007, p. 377).

However, it should be noted that several authors do not provide a clear definition of the employee life cycle. Instead, the content of the notion can be derived from the general description provided in various sources (Smither, 2003; Verive \& DeLay, 2006; Costello, 2006; Thompsen, 2010; Welty, 2009; Eaton Gaul, 2019; Lawrence, 2017). Other authors use such terms as "concept" (Shyam \& Ramachandra Gowda, 2015), "model” (Lavelle, 2007; Thompsen, 2010; Farnan et al., 2010; Rouse, 2019;
Lowenstein, 2017), "method" (Tabassum \& Sahni, 2017; Biasi, 2017), "way" (Burke, 2019), "process" (Gutierrez, 2017) and "progression" (Leung, 2018) as the basic terms to interpret the essence of the employee life cycle. All these terms have different meanings and reflect a broad or strict sense of "employee life cycle" definition. A more detailed analysis was required to validate the correctness of the use of these terms in relation to the employee life cycle within an organization. This analysis allowed us to draw the following conclusions.

The term "concept" is used to interpret employee life cycle as: "a concept in human resource management that describes the stages of an employee's time with a particular company and the role the human resources department plays at each stage" (Shyam \& Ramachandra Gowda, 2015 , p. 21). According to the Cambridge Dictionary "concept - is an idea, theory, etc. about a particular subject" (Cambridge Dictionary, 2019). Accepting this definition, the employee life cycle could be seen as one of the theories used in marketing that describes the general rules of the relationship between the employee and the employer. However, for practical use, this interpretation is too broad and does not allow conveying the essence of the employee life cycle.

The term "model" is used by several authors (Lavelle, 2007; Farnan et al., 2010; Rouse, 2019; Lowenstein, 2017), interpreting the employee life cycle as: "a versatile model that is capable of playing several key roles in the manpower planning process" (Lavelle, 2007, p. 377); “a model 
is implemented through five components" (Farnan et al., 2010, p. 4); "an HR model that identifies the different stages a worker advances through in an organization and the role HR plays in optimizing that progress" (Rouse, 2019); "an HR-based model that identifies stages in employees" careers to help guide their management and optimize associated processes" (Lowenstein, 2017). In the dictionary "model - is something that a copy can be based on because it is an extremely good example of its type" (Cambridge Dictionary, 2019). That said, the theoretical model of the employee life cycle allows us to describe the career stages an employee is going through within an organization depending on various factors, and to display the stages (for example, in graphical or any other form). The use of the term "model" alike the term "concept" entails addressing the broad essence of the notion of the employee life cycle.

The term "method" in the dictionary is defined as "a particular way of doing something" (Cambridge Dictionary, 2019). Based on the basic concept of a life cycle, it can be argued that the life cycle itself is not a method. The proposed definitions either reflect methods that are used to manage the employee of the enterprise at various stages of their life cycle (Tabassum \& Sahni, 2017), or characterize modeling as a method of visualizing an employee's relationship with their employer (Biasi, 2017). The same can be concluded for the usage of the term "way" (Burke, 2019) which stands for "an action that can produce the result you want; a method" (Cambridge Dictionary, 2019), or "a method, style, or manner of doing something; an optional or alternative form of action" (Oxford Reference, n.d.).

The use of the term "progression" as "a natural progression of phases in the way an employee interacts with your organization" (Leung, 2018) indicates the development of employment relationships in only one direction, since "progression is the process of changing or developing towards an improved situation or state" (Cambridge Dictionary, 2019). Employee-employer relations may both be improved or deteriorated. Thus, while defining the employee life cycle it would be correct to take into account the term "regression", which means "a return to a previous and less advanced or worse state, condition, or way of behaving" (Cambridge Dictionary, 2019). Such bi-directionality of employment relations between an employee and an employer should be reflected in the life cycle definition.

The term "process" is defined as "a series of actions or events performed to make something or achieve a particular result or a series of changes that happen naturally" (Cambridge Dictionary, 2019). Thus, the employee life cycle may be represented as a process characterizing changes in the relationship between an employee and their employer in time. The process itself is represented by separate stages scattered along the relationship timeline. The interaction may begin from the moment the employer creates or publishes a job post and the future employee responds to it, and may end with the initiation of a relation's termination by one of the parties.
Based on the fundamental definition, it is suggested to understand the employee life cycle within an organization as a period of time during which an employee and an employer interact with each other and develop their bilateral relationship.

We suggest the employee-employer interaction can be: a) translated through the bases of a concept, b) illustrated as a model c) designed as a process. Taking that into consideration we will be also aiming at interpreting the suggested basic theoretical components throughout the further research stages.

\subsection{Does the ELC have a "product-based" or a "client-based" approach?}

When it comes to comparing the employee life cycle with a product or with a customer life cycle, disagreements among researchers are evident. There is a part of sources where we could clearly identify a "product-based" approach, while in other sources the "client-based" approach lies at the core of the employee life cycle. Smither (2003), Tabassum and Sahni (2017), Shyam and Ramachandra Gowda (2015) perceive the life cycle of the employee as the product life which is defined as "a framework in which to view the challenge of retaining employees can be derived from the product life-cycle model used by marketing experts" (Smither, 2003, p. 20). Tabassum and Sahni (2017) give a similar definition: "as we have acknowledged about PLC, Product Life Cycle, the same procedure very much applies to the Employees Life Cycle" (p. 5445). Shyam and Ramachandra Gowda (2015) also compare an employee to the product "like a product, an employee is also going through different stages in his/her employee life in an organization" (p. 21).

While in other sources (Lowenstein, 2017; Biasi, 2017) it is evident that the employee life cycle is compared to the client's life cycle. For instance "in many respects the employee life cycle is similar to the customer life cycle" (Lowenstein, 2017) or as Biasi (2017) put it: "the ELC model is based on the idea that companies should design the employee experience as carefully as their customer's experience" (Biasi, 2017).

We believe that the inconsistency of views exists due to the lack of clearly elaborated conceptual bases applicable to the development of the employee life cycle. In this research, we suggest taking as bases the conceptual framework of personnel marketing, elaborated in the previous researches and following the principles of marketing (Kotler et al., 2008). These bases were developed from the perspective of an employer and they include "actions to build and maintain desirable exchange relationships" (Kotler et al., 2008). In this paper we advocate that such a relationship is the "employee-employer interaction", they are customer-centered, and employees (existing and potential) are treated as customers by employers. This relation has three following characteristics. (1) The object of the employer's attention is the target audience - the personnel (existing and potential), as well as their needs and the 
requirements they put forward to potential and existing employers on the labor market. (2) An employer integrates and coordinates activities to ensure personnel satisfaction, thus ensuring itself in required personnel by creating and supporting the personnel satisfaction. (3) An employer offers what is necessary to its consumers (personnel) and provides coverage of its needs in required personnel by satisfying its needs. Searching for the required personnel, the organization offers a type of product that could satisfy the personnel needs.

Since the customer life cycle is linked to the customer product, it is also recommended to use the personnel marketing product from the perspective of the employer. This product is "a job" (or "a position") with its qualitative and quantitative characteristics that an employer offers to its personnel (existing and potential) (Kryvoruchko \& Glad$\mathrm{ka}, 2015)$. Likewise, the classical marketing product (Kotler et al., 2008), the personnel marketing product is suggested to be represented at three levels. The first level - the core benefit - is the job/position as conceived by the employer and the main benefit or service that the employer offers to its candidate. Second level - actual product - the candidate is offered a specific job/position with its qualitative and quantitative characteristics (e.g. professional and personal requirements for the future employee, job description, employment conditions, rights, obligations, duration, etc.) Third level - augmented product - the candidate is offered an expected job/position (with quantitative and qualitative characteristics) as well as a package of services related to this position (e.g. advantages or benefits that the candidate receives within the organization after joining it).

The essence of personnel marketing product consists in the following:

a) On the external labor market, the employer promotes its product (job/position) along with quantitative and qualitative characteristics, as well as the package of services that he "promises" to provide to the candidate after the candidate "purchases" the proposed product. The product purchase is the moment of bilateral signing of the contract (e.g. labor/employment agreement). Thus, on the external labor market, the employer deals with the promotion of "products" and attraction of new employees, applying the same principles that are included in "products marketing" (Kotler et al., 2008);

b) On the internal labor market, when the candidate becomes an employee, the employer provides them with the necessary product (job/position) along with a package of services that were proposed as reinforcements to this product. Thereby the employer fulfills the conditions of the signed contract with the employee. Hence, internally, the employer deals with the retention of existing employees, applying the same principles as for "services marketing" (Kotler et al., 2008).

Based on the conceptual framework of personnel marketing we argue that the employee life cycle development should be similar to the customer life cycle. Defined by three levels, suggested personnel marketing product initiates around the employee a customer-centric process on the labor markets (external and internal). This justifies the need to build the employee life cycle that would integrate activities and tools of external and internal personnel marketing that will help to attract employees to and retain them within an organization.

\subsection{What does the ELC start from?}

There are also disagreements among researchers regarding the starting moment of the employee life cycle. The analysis of previous researches allows us to split the authors into three categories. The first group of authors believes that the ELC begins from the moment an employee assumes a new position (Smither, 2003; Shyam \& Ramachandra Gowda, 2015; Lavelle, 2007). The second group includes into the ELC the stages of recruitment and selection (Tabassum \& Sahni, 2017; Costello, 2006; Farnan et al., 2010; Saltmarsh, 2017; Rouse, 2019; Smither, 2003; Tabassum \& Sahni, 2017; Shyam \& Ramachandra Gowda, 2015; Lavelle, 2007; Costello, 2006; Farnan et al., 2010; Saltmarsh, 2017; Welty, 2009; Rouse, 2019; Cattermole, 2019; Burke, 2019; Eaton Gaul, 2019; Leung, 2018; Gutierrez, 2017; Lowenstein, 2017; Biasi, 2017; Lawrence, 2017). The third group suggests to include either the stage of an employee attraction (Verive \& DeLay, 2006; Burke, 2019; Eaton Gaul, 2019; Leung, 2018) or other related pre-recruitment processes (Thompsen, 2010; Welty, 2009; Gutierrez, 2017).

We believe that attraction and retention are the two main employer's cycles of activities, which are aimed at building relationships between an employee and an organization. The more efficient the process, the longer is the employee life cycle within an organization.

Employer's cycle of attraction activities may include stages related not only to recruitment but also to position planning, identification of duties and responsibilities, to the specification of required skills and knowledge. This is followed by the job posting in all internal and/or open sources. If the position requirements are correctly defined and if they are published in the right sources, less time is needed to create a pool of right candidates. If a potential employee feels the conformity of their personal and professional qualities with the requirements, they will respond to the job posting and will get into the pool of candidates. Recruitment is aimed to bring the right number of candidates to the right positions within the organization. While hiring an employee, it is necessary to take into account not only their professional skills, but also the relevance of their personal values to the offered job/position, as well as identify how these values may fit into the corporate culture of the organization. The effectiveness of the employee at the workplace, the success of their development, career progression and self-realization largely depend on how accurate the staffing process was carried out. 
From the moment when an employee starts working in the organization, the employer's cycle of retention activities begins. If the employee is not satisfied with the job/position, with the opportunities for self-realization, and the assigned tasks and duties, they will leave the organization after a short period. In this case, retention activities will be ineffective. This emphasizes that the processes of attraction and retention are closely interrelated, and their stages complement one another.

Thus, the chain of employee life cycle should not begin from the moment when an employee assumes a position, but rather from the moment when an employee begins to go through the stages familiarizing themselves with the organization on the labor market and with its employer value proposition $\left(E V P^{2}\right)$.

\subsection{Should the ELC be described from the perspective of an employer or an employee?}

In the reviewed literature authors describe the ELC from one of the two different perspectives: from the perspective of the employer or the perspective of the employee. We used the two criteria to judge either of these perspectives: roles of the employee and the employer ("active" or "passive") and the effectiveness of described activities (if they may reflect the employer or the employee's results of work).

From the perspective of the employer, the ELC reflects particular activities that an employer is actively taking to lead an employee through career stages. The effectiveness of its activities shows the results of the employer's work. The employee's role is "passive" in this case. For example, the employee life cycle is analyzed from the employer's perspective by Tabassum and Sahni (2017); Costello (2006); Farnan et al. (2010); Saltmarsh (2017); Welty (2009); Rouse (2019); Cattermole (2019); Eaton Gaul (2019); Leung (2018); Gutierrez (2017); Lowenstein (2017); Biasi (2017); Lawrence (2017). For instance, Saltmarsh (2017) characterizes the "recruitment" stage as action of hiring; "education" stage includes actions aiming to familiarize new employees with corporate culture, values, job description; "motivation" stage describe action that should motivate employee at their job; "evaluation" stage - is the one where an employer appraises/evaluates the employee performance (Saltmarsh, 2017, pp. 8-9). The activities' effectiveness may result in the following: number of received and pre-screened CVs, number of conducted interviews, number of conducted on-boarding programs, number and set of programs and tools available to motivate employees etc.

The employer's role becomes "passive" when the ELC is described from the perspective of an employee. It implies the activities that the employee is actively taking by

\footnotetext{
2 EVP - stands for an Employer Value Proposition and defined as a set of qualities and characteristics of the employer, which serve to create the attractiveness of an employer to attract or retain target audiences on the external labor market or internally accordingly (Author).
}

themselves within an organization. Their effectiveness may reflect the results of the employee's work. Precisely, Shyam and Ramachandra Gowda (2015) analyze the life cycle from the perspective of the employee: "introduction" stage is characterized as "a period of slow performance as the talent has just been recruited to take up the challenging tasks of the organization"; "development" stage as "a period of high performance and productivity as a result of intense training and development programs aiming to improve their knowledge, sharpen their skills and mold their attitude"; during "promotion" stage "employees will divert from the regular work they performed and look for higher order tasks"; "Mid-Career Crisis/Retirement" characterized by "decline, bottoming out and are the unhappiest, citing career anxiety, career unease, worker stress, loneliness and relationship troubles and careers stalls; during the retirement stage, employees will withdraw themselves from the regular operations of the company" (Shyam \& Ramachandra Gowda, 2015, p. 23). Other sources (Smither, 2003; Verive \& DeLay, 2006; Lavelle, 2007) define the employee life cycle in similar terms. The effectiveness of these activities may be interpreted as follows: employee's KPIs, number and percentage of regular and additional tasks performed, a number of completed cross-functional projects etc.

As identified above, the employee life cycle is an employee-employer interaction. We believe that any interaction between an employee and an employer cannot be separated from each other, and therefore cannot be developed from the perspective of only one of the participants. This is explained by the fact that the actions of employees and employers are closely interconnected and predetermine each other. For example, an employee joins an organization (or wants to move to another position/ team, etc. within the organization) due to activities and measures of external (or internal) personnel marketing. At the same time, the choice of an employee for a specified position is determined by a set of their personal qualities, as well as professional skills and abilities.

We believe that the employee life cycle is a both-way employee-employer interaction and it cannot be described from the perspective of only one of the sides. On the one hand, it should reflect the employer's cycles of activities related both to attraction and/or retention of an employee. On the other hand, it should show the employee's activities at each stage of this relations period. Each stage may be characterized by employee engagement and its cyclic change.

\section{Research results and discussion}

\subsection{Model of the employee life cycle}

While implementing any personnel marketing activities and taking an employee through different processes of the identified employer's cycles of activities related to attraction and retention it is crucial to create employer attractiveness. In the framework of this study we believe that the EVP enables an employer to successfully attract potential 
and retain existing employees, accordingly: 1) if on the labor market, the "perceived" EVP corresponds to all those specific requirements that potential employee requests from the future employer; 2) if internally, the "received" EVP meets all formed expectations of the employee.

We believe that relationship duration will largely depend on the strength of motivation of the employees to perform their duties. When assuming a new role, an employee tries their best to show maximum efficiency during the first period of time. The employee's further performance will depend on how much the work performed is suitable for them, as well as on the internal opportunities provided by the employer as to the personal and professional growth. However, when the duties become routine and/or begin to be "mechanical" or the employee gradually loses interest in the job, they start experiencing career stagnation (Abele et al., 2012) or professional burnout (Kahn, 1990). That is why one of the most important tasks of management is to constantly monitor the employee's interest to work in order to prevent professional burnout, career stagnation. In practice, the level of employee motivation and involvement is being monitored through employee engagement.

As suggested by the Chartered Institute of Professional Development "the notion of employee engagement repackages various concepts, in particular motivation and commitment, and emphasizes both employees' well-being and performance. As such, it offers a mutual gain view of the employment relationship, seeking the good of employees and the organization in tandem" (Chartered Institute of Personnel and Development, 2019). The engagement theory was suggested by Kahn in 1990 (Kahn, 1990). It was further developed as opposed to the burnout in the works of Schaufeli et al. (2002). In his work, Castellano (2013) approves "if engagement requires a degree of energy, it stands to reason that the opposite of engagement can be described as burnout. Burnout is a reaction to chronic occupational stress resulting in the draining of physical, cognitive, and emotional resources and characterized by emotional exhaustion and cynicism, that is a negative, callous, and cynical attitude toward one's job" (Castellano, 2013, p. 97). It is worth mentioning, that a lot of authors have already focused their researches on employee engagement and its measurement (Imandin et al., 2014; Burnett \& Lisk, 2019; Einarsen et al., 2018; Shirin \& Kleyn, 2017; Ladyshewsky \& Taplin, 2017; Shantz et al., 2016; Saks \& Gruman, 2014; Biggs et al., 2014; Handa \& Gulati, 2014; Kovjanic et al., 2013). To measure employee engagement authors identify employee engagement constructs (Imandin et al., 2014), identify factors or antecedents that may have an impact on the work engagement (Einarsen et al., 2018; Shirin \& Kleyn, 2017; Ladyshewsky \& Taplin, 2017; Biggs et al., 2014; Handa \& Gulati, 2014; Kovjanic et al., 2013; Dollard \& Bakker, 2010; Hamidu Magem, 2017; Kimberley et al., 2014), analyze tools to conduct surveys allowing gathering employees' feedback regularly (Burnett \& Lisk, 2019); identify or develop scales to measure engagement (Saks \& Gruman, 2014; Soane et al., 2012), conduct research to identify the link of employee engagement on the deviant behavior and turnover (Shantz et al., 2016; Psychometrics, Consulting Company, 2015).

We believe that employee engagement is changing cyclically throughout the whole period of ELC as well as it is subject to cyclical swings on each stage of ELC. As it was mentioned above, professional burnout may occur when the employee achieves professional maturity, when their old responsibilities become habitual, they gradually lose interest to perform them. To revitalize the employee engagement on each of the ELC stages, the organization is advised to timely implement personnel marketing measures. The measures may include actions aiming to diversify the employee's responsibilities (e.g. assign them to another area of work within the team, to a new project, offer a part-time secondment to another team, etc.). The effectiveness of the actions can result in the renewed growth of employee engagement on the specified ELC stage. This effect will last until the newly assigned responsibilities become habitual again and the new risk of disengagement burnout appears. At some point, the employee should be moved to the new stage of the ELC within the organization to prevent their resignation.

We suggest the above mentioned can be illustrated as a Model of the employee life cycle (Figure 1).

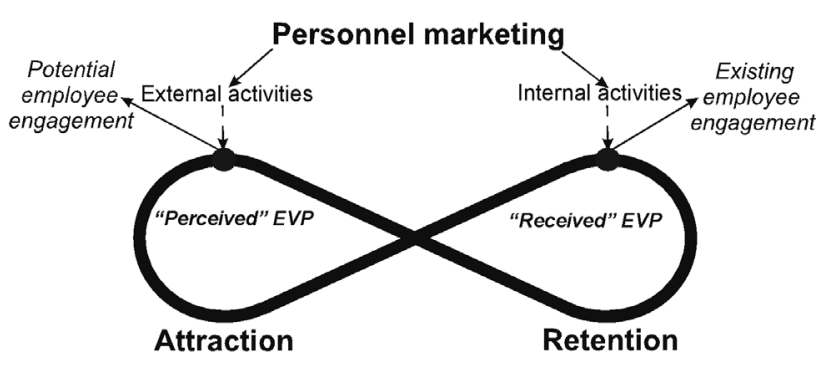

Figure 1. Model of the employee life cycle

\subsection{Refining definition "Employee life cycle within an organization"}

Based on the foregoing, we propose a new definition of the employee life cycle within an organization as follows: it is the period of time of employee-employer interaction, which begins from the moment of attraction of the required employee on the labor market and lasts until their employment termination; this is the period of time during which the employer develops and implements appropriate personnel marketing measures within the cycles of attraction and retention (that help to create and provide its EVP externally and internally accordingly) that lead the employee through several employment stages, characterized by cyclical changes of their engagement level. Unlike other definitions the suggested one identifies the employee life cycle as the period of time of employee-employer interaction. This period is characterized by cyclical changes of employee's engagement level (during the whole ELC and within each stage of the ELC) and by personnel marketing measures that an employer applies within the cycles of attraction and retention. 


\subsection{Titles and characteristics of the ELC stages}

As it was discussed above the researchers characterize the stages of the ELC either from the employer's perspective (Biasi, 2017; Burke, 2019; Eaton Gaul, 2019; Farnan et al., 2010; Tabassum \& Sahni, 2017; Verive \& DeLay, 2006; Saltmarsh, 2017; Leung, 2018) or from the employee's perspective (Smither, 2003; Shyam \& Ramachandra Gowda, 2015; Lowenstein, 2017). The ELC stages titles also reflect the actions of one of the sides. In this regard, we suggest more versatile titles for the ELC stages. They may combine characteristics and may be meaningful both for the employer and for the employee. Therefore they can reflect actions for both participants simultaneously. The suggested titles and characteristics of the ELC stages are presented in Table 4.

We suggest a set of measures are to be implemented on each stage of the ELC to maintain or renew the employee engagement level. Examples of general recommendations were developed by authors and presented in Table 5 hereafter.

Table 4. Titles and characteristics of the ELC stages

\begin{tabular}{|c|c|c|}
\hline \multirow{2}{*}{$\begin{array}{l}\text { Titles of the ELC } \\
\text { stages }\end{array}$} & \multicolumn{2}{|c|}{ Characteristic of the ELC stages from the perspective of the } \\
\hline & employee & employer \\
\hline \multicolumn{3}{|c|}{ Attraction } \\
\hline $\begin{array}{l}\text { Search and } \\
\text { Discover }\end{array}$ & $\begin{array}{l}\text { Labor market analysis and development of } \\
\text { expectations towards potential employers }\end{array}$ & $\begin{array}{l}\text { Labor market analysis and development of } \\
\text { requirements towards candidates }\end{array}$ \\
\hline $\begin{array}{l}\text { Consider and } \\
\text { Apply }\end{array}$ & $\begin{array}{l}\text { Job postings analysis and } \\
\text { response to the selected ones }\end{array}$ & Search and attraction of candidates \\
\hline Assess & $\begin{array}{l}\text { Participation in evaluations and/or interviews; } \\
\text { evaluation of job offer }\end{array}$ & $\begin{array}{l}\text { Pre-screening and selection through evaluations and } \\
\text { interviews; making the final decision }\end{array}$ \\
\hline Accept & $\begin{array}{l}\text { Acceptance of the job offer; } \\
\text { contract signing }\end{array}$ & $\begin{array}{l}\text { Pre-hiring checks; } \\
\text { contract preparation }\end{array}$ \\
\hline \multicolumn{3}{|c|}{ Retention } \\
\hline Explore & On-boarding & Organization of the employee on-boarding \\
\hline Build-up & $\begin{array}{l}\text { Acquiring necessary knowledge; } \\
\text { performing core duties }\end{array}$ & $\begin{array}{l}\text { Ensuring the core and necessary training; } \\
\text { employee assessment }\end{array}$ \\
\hline Maturity & Achieving performance maturity & Monitoring of employee's satisfaction and performance \\
\hline $\begin{array}{l}\text { Repeat or decline } \\
\text { and leave }\end{array}$ & $\begin{array}{l}\text { Expansion of professional horizons; horizontal / } \\
\text { vertical move or leave }\end{array}$ & $\begin{array}{l}\text { Providing with additional professional opportunities, } \\
\text { employment termination }\end{array}$ \\
\hline
\end{tabular}

Table 5. Employee engagement measures for each stage of the ELC

\begin{tabular}{|c|c|c|c|c|c|c|c|c|}
\hline \multirow[b]{3}{*}{ Measures } & \multicolumn{8}{|c|}{ Titles of the ELC stages } \\
\hline & \multicolumn{4}{|c|}{ Attraction } & \multicolumn{4}{|c|}{ Retention } \\
\hline & 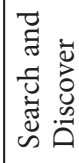 & 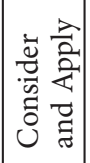 & $\begin{array}{l}\infty \\
\infty \\
\infty \\
\infty \\
\&\end{array}$ & $\frac{\vec{u}}{\ddot{z}}$ & 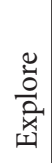 & 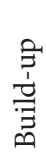 & 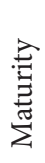 & 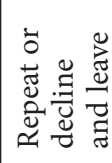 \\
\hline 1 & 2 & 3 & 4 & 5 & 6 & 7 & 8 & 9 \\
\hline Communicate corporate goals and values to candidates and employees & + & + & + & + & + & + & + & + \\
\hline $\begin{array}{l}\text { Create an effective recruitment campaign ensuring the right candidates to apply (select } \\
\text { and collaborate with universities, recruitment agencies, elaborate recruitment KPIs and } \\
\text { measurement tools, develop employee referral programs, etc.) }\end{array}$ & + & + & & & & & & \\
\hline $\begin{array}{l}\text { Identify appropriate assessment criteria and communicate them to the potential } \\
\text { candidates (externally and internally) }\end{array}$ & + & + & + & & & & & \\
\hline Communicate effectively the EVP & + & + & + & & & & & \\
\hline $\begin{array}{l}\text { Invest into the development of IT tools allowing candidates easily to apply to vacancies } \\
\text { and recruitment teams to manage pools of candidates }\end{array}$ & + & + & + & + & & & & \\
\hline $\begin{array}{l}\text { Provide mentorship programs and coaching sessions for potential employees (at } \\
\text { universities campuses, employment centers) }\end{array}$ & + & + & & & & & & \\
\hline $\begin{array}{l}\text { Create volunteer positions allowing potential candidates to contribute to the corporate } \\
\text { projects }\end{array}$ & + & + & & & & & & \\
\hline Organize external competitions and challenges for external candidates & + & + & & & & & & \\
\hline
\end{tabular}


End of Table 5

\begin{tabular}{|c|c|c|c|c|c|c|c|c|}
\hline 1 & 2 & 3 & 4 & 5 & 6 & 7 & 8 & 9 \\
\hline Offer open-door days and organize on-site visits to external candidates & + & & & & & & & \\
\hline Organize corporate training and internal mentorship programs & & & & & + & + & + & + \\
\hline $\begin{array}{l}\text { Outline employees personal contribution to the achievement of the overall goals of the } \\
\text { organization }\end{array}$ & & & & & + & & & \\
\hline $\begin{array}{l}\text { Create effective internal communication channels to update employees on the business } \\
\text { activities and initiatives }\end{array}$ & & & & & + & + & + & + \\
\hline $\begin{array}{l}\text { Create effective external communication channels to help candidates to familiarize } \\
\text { themselves with the business activities and initiatives of the organization }\end{array}$ & + & + & + & + & & & & \\
\hline Provide employees with various feedback tools & & & & & + & + & + & + \\
\hline $\begin{array}{l}\text { Provide on-line anonymous surveys to "measure" team members' satisfaction level } \\
\text { (satisfaction of work environment, relations, leadership, psychological wellness and } \\
\text { grow opportunities) }\end{array}$ & & & & & + & + & + & + \\
\hline $\begin{array}{l}\text { Provide additional assistance or guidance to managers in developing communication } \\
\text { initiatives for their teams (such as informal meetings and chats, virtual potluck and } \\
\text { other) }\end{array}$ & & & & & + & + & + & + \\
\hline Stimulate the development and implementation of know-how at work & & & & & & + & + & \\
\hline Ensure comfortable conditions of remote work or in the office & & & & & + & + & + & + \\
\hline $\begin{array}{l}\text { Inform employees about additional growth and development opportunities, creation } \\
\text { of additional growth and development opportunities through participation in cross- } \\
\text { departmental projects }\end{array}$ & & & & & & + & + & + \\
\hline $\begin{array}{l}\text { Create space to address any issue of employees concerns (e.g. remote Q\&As with top } \\
\text { managers, HR and IT teams) }\end{array}$ & & & & & + & + & + & + \\
\hline $\begin{array}{l}\text { Create space for all managers (virtual or not) for meetings and forums to discuss } \\
\text { common issues or concerns and brainstorm on the possible solutions }\end{array}$ & & & & & & & + & + \\
\hline $\begin{array}{l}\text { Create space to share non-work related knowledge and experience: provide space in } \\
\text { organizing on-line workshops, on-line concerts, books/articles discussions, etc. }\end{array}$ & & & & & + & + & + & + \\
\hline $\begin{array}{l}\text { Anticipate the creation of non-work-related groups, where employees can exchange } \\
\text { ideas and information }\end{array}$ & & & & & + & + & + & + \\
\hline $\begin{array}{l}\text { Provide innovative tools for daily communication: use video and voice messages } \\
\text { instead of e-mails, use team chats to quickly exchange work-related issues and get } \\
\text { peers to advise and help }\end{array}$ & & & & & + & + & + & + \\
\hline $\begin{array}{l}\text { Give the possibility to employees to take on-line psychological/anxiety tests and to } \\
\text { decide by themselves whether they would need further psychological assistance }\end{array}$ & & & & & + & & & \\
\hline $\begin{array}{l}\text { Provide employees with additional psychological counseling and other assistance } \\
\text { including Coaching sessions, Psychological support, extended access to Employee and } \\
\text { Family Assistance Program }\end{array}$ & & & & & + & + & + & + \\
\hline Prepare guidelines as to the prevention of psychological health problems & & & & & + & + & + & + \\
\hline $\begin{array}{l}\text { Conduct an awareness campaign among all employees about the mental health } \\
\text { importance through a set of on-line and/or in-class info sessions; through a variety } \\
\text { of info leaflets and/or internal web-page (videos, articles, e-books); trough open } \\
\text { discussions of information during team meetings }\end{array}$ & & & & & & + & + & \\
\hline Support individual initiatives to conduct work-related workshops and training sessions & & & & & & & + & + \\
\hline $\begin{array}{l}\text { Incorporate training sessions, providing employees with effective preventive and self- } \\
\text { care tools and practices }\end{array}$ & & & & & & + & + & \\
\hline $\begin{array}{l}\text { Provide employees with Conflict resolution training sessions (effective negotiation } \\
\text { methods and appropriate assertiveness) and Relaxation practices sessions (enhanced } \\
\text { ability to remain physically relaxed and mentally calm despite ongoing stresses, } \\
\text { whether through specific relaxation techniques or exercise) }\end{array}$ & & & & & & + & + & \\
\hline
\end{tabular}


More specific measures are to be developed in response to the organizational needs and in accordance with the identified potential and existing employees' engagement level.

\section{Conclusions}

Based on the literature sources review and analysis we could answer the main questions raised at the beginning. First, we developed the concept of the employee life cycle within an organization. To achieve this goal, a conceptual framework of personnel marketing was adopted and it was substantiated that the employee life cycle is comparable to the customer life cycle. An employee should be treated as a client and all activities related to its life cycle within an organization should be client-oriented.

According to the suggested concept, at each stage of the employee life cycle, the employer should use tools of external and internal personnel marketing. Furthermore, the employee life cycle should describe processes occurring simultaneously from the employer's and the employee's perspectives. On the one hand, it reflects the activities that the employer implements within the attraction and retention cycles; on the other hand, the definition reflects employee life cycle stages that an employee is going through in response to the appropriate employer's activities and that might be characterized by the employee engagement.

Secondly, we developed a model of the employee life cycle within an organization, following which employer should develop its value proposition on the labor market and internally to ensure the ongoing development of interrelated attraction and retention cycles of activities. This definition reflects the above conceptual provisions of the employee life cycle within an organization.

Thirdly, we identified the essence of the ELC definition. The proposed definition is distinguished from the others as it interprets the life cycle as a time that characterizes the interaction of the employee with the employer from the moment he attracted his attention on the labor market until the moment he was fired.

This paper represents the fundamental theoretical bases for future research directions. Further researches will be dedicated to the development of measurement methods allowing to identify employee engagement at each of the ELC stages. The practical implication of the developed theoretical bases will imply the development of the specific personnel marketing measures in accordance with the identified level of employee engagement ensuring the right personnel is attracted and retained within the organization.

\section{References}

Abele, A. E., Volmer, J., \& Spurk, D. (2012). Career stagnation: Underlying dilemmas and solutions in contemporary work environments. In N. P. Reilly, M. J. Sirgy, \& C. A. Gorman (Eds.), International handbooks of quality-of-life. Work and quality of life: Ethical practices in organizations (pp. 107-132). Springer Science + Business Media.

https://doi.org/10.1007/978-94-007-4059-4_7

Beer, M., Spector, B., \& Lawrence, P. R. (1984). Managing human assets. Free Press.

Biasi, N. (2017). The 5 stages of the employee lifecycle. https:// www.starmeup.com/blog/en/useful-tips/employee-lifecycle/

Biggs, A., Brough, P., \& Barbour, J. P. (2014). Strategic alignment with organizational priorities and work engagement: A multi-wave analysis. Journal of Organizational Behavior, 35(3), 301-317. https://doi.org/10.1002/job.1866

Breevaart, B., Bakker, A., Hetland, J., Demerouti, E., Olsen, O. K., \& Espevik, R. (2014). Daily transactional and transformational leadership and daily employee engagement. Journal of Occupational \& Organizational Psychology, 87(1), 138-157. https://doi.org/10.1111/joop.12041

Bureau of Labour Statistics. (2018). Employee Tenure in 2018. https://www.bls.gov/cps/

Burke, M. (2019). Six stages to success with the employee lifecycle. https://inside.6q.io/six-stages-to-success-with-the-employeelifecycle/

Burnett, J. R., \& Lisk, T. C. (2019). The future of employee engagement: Real-Time monitoring and digital tools for engaging a workforce. International Studies of Management \& Organization, 49(1), 108-119.

https://doi.org/10.1080/00208825.2019.1565097

Cambridge Dictionary. (2019). Cambridge Dictionary of American English. https://dictionary.cambridge.org/

Castellano, W. G. (2013). Practices for engaging the 21st century workforce. Pearson Education, Inc.

Cattermole, G. (2019). Developing the employee lifecycle to keep top talent. Strategic HR Review, 18(6), 258-262.

https://doi.org/10.1108/SHR-05-2019-0042

Chartered Institute of Personnel and Development. (2019). Employee engagement and motivation. CIPD. https://www.cipd. co.uk/

Costello, D. (2006). Leveraging the employee life cycle: Four ways to stem sales force turnover. Customer Relationship Management, December, 10(12), 48.

Dollard, M. F., \& Bakker, A. B. (2010). Psychosocial safety climate as a precursor to conducive work environments, psychological health problems, and employee engagement. Journal of Occupational and Organizational Psychology, 83(3), 579-599. https://doi.org/10.1348/096317909X470690

Eaton Gaul, C. (2019). Agile employee lifecycle. https://www.rsm. global/southafrica/news/agile-employee-lifecycle/

Einarsen, S., Skogstad, A., Rørvik, E., Lande, A. B., \& Nielsen, M. B. (2018). Climate for conflict management, exposure to workplace bullying and work engagement: A moderated mediation analysis. The International Journal of Human Resource Management, 29(3), 549-570.

https://doi.org/10.1080/09585192.2016.1164216

Farnan, J., Anderton, M. Z., \& Douglas, E. (2010). The ROI of talent: How the employee lifecycle can improve business efficiency. http://www.skillsoft.com/assets/offers/ExecBlueprintsThe_ROI_of_Talent.pdf/

Gladka, O., \& Fedorova, V. (2019). Defining personnel marketing strategies. Business: Theory and Practice, 20, 146-157. https://doi.org/10.3846/btp.2019.14

Gutierrez, K. (2017). The importance of training in each stage of the employee lifecycle. https://www.shiftelearning.com/blog/ training-in-each-stage-of-the-employee-lifecycle/

Hamidu Magem, I. (2017). A review of the antecedents and consequences of employee engagement. World Academy of 
Science, Engineering and Technology International Journal of Economics and Management Engineering, 11(4), 773-780.

Handa, M., \& Gulati, A. (2014). Employee engagement. Does individual personality matter. Journal of Management Research, 14(1), 57-67.

Imandin, L., Bisschoff, C., \& Botha, C. (2014). A model to measure employee engagement. Problems and Perspectives in Management, 12(4), 520-532.

Kahn, W. A. (1990). Psychological conditions of personal engagement and disengagement at work. Academy of Management Journal, 33(4), 692-724. https://doi.org/10.2307/256287

Kotler, P., Armstrong, G., \& Cunningham, P. H. (2008). Principles of marketing (7th Canadian Ed.). Pearson Prentice Hall.

Kovjanic, S., Schuh, S. C., \& Jonas, K. (2013). Transformational leadership and performance: An experimental investigation of the mediating effects of basic needs satisfaction and work engagement. Journal of Occupational and Organizational Psychology, 86(4), 543-555. https://doi.org/10.1111/joop.12022

Kryvoruchko, O., \& Gladka, O. (2015). Marketynh personalu: formuvannya ta realizatsiya na pidpryyemstvakh [monohrafiya]. KhNADU.

Ladyshewsky, R., \& Taplin, R. (2017). Employee perceptions of managerial coaching and work engagement using the Measurement model of coaching skills and the Utrecht work engagement scale. International Journal of Evidence Based Coaching and Mentoring, 15(2), 25-42.

Lavelle, J. (2007). On workforce architecture, employment relationships and lifecycles: Expanding the purview of workforce planning \& management. Public Personnel Management, 36(4), 371-385. https://doi.org/10.1177/009102600703600406

Lawrence, M. T. (2017). Part of the automation, analytics and data in HR. https://www.hrzone.com/perform/business/ employee-lifecycle-get-deeper-insight-by-aligning-analyticsinitiatives/

Leung, I. (2018). Employee lifecycle. https://enboarder. com/2018/12/11/employee-engagement-lifecycle/

Lowenstein, M. (2017). Customers have life cycles. Guess what? So do employees! Here's why that's so important.

https://beyondphilosophy.com/customers-life-cycles-guessemployees-heres-thats-important/

Moynihan, D. P., \& Landuyt, N. (2008). Explaining turnover intention in state government: Examining the roles of gender, life cycle, and loyalty. Review of Public Personal, 28(2), 120-143. https://doi.org/10.1177/0734371X08315771

Oxford Dictionary. (2019). Oxford Advanced Learner's Dictionary. https://www.oxfordlearnersdictionaries.com/

Oxford Reference. (n.d.). https://www.oxfordreference.com/

Psychometrics, Consulting Company. (2015). A Study of employee engagement in the Canadian workplace. https://www. psychometrics.com/

Rouse, M. (2019). Employee life cycle. https://searchhrsoftware. techtarget.com/definition/employee-life-cycle/

Saks, A. M., \& Gruman, J. A. (2014). What do we really know about employee engagement? Human Resource Development Quarterly, 25(2), 155-182.

https://doi.org/10.1002/hrdq.21187
Saltmarsh, M. (2017). 5 Stages of the employment life cycle in need of improvement. Hospitality Review, February, 8-9.

Sato, Y., Kobayashi, N., \& Shirasaka, S. (2019). An analysis of human resource management for knowledge workers: Using the three axes of target employee, lifecycle stage, and human resource flow. Review of Integrative Business and Economics Research, 9(1), 140-156.

Schaufeli, W. B., Salanova, M., Gonzalez-Roma, V., \& Bakker, A. B. (2002). The measurement of engagement and burnout: A two sample confirmatory factor analytic approach. Journal of Happiness Studies, 3(1), 71-92. https://doi.org/10.1023/A:1015630930326

Shantz, A., Alfes, K., \& Latham, G. P. (2016). The buffering effect of perceived organizational support on the relationship between work engagement and behavioral outcomes. Human Resource Management, 55(1), 25-38. https://doi.org/10.1002/hrm.21653

Shirin, A., \& Kleyn, N. (2017). An evaluation of the effects of corporate reputation on employee engagement: The case of a major bank in South Africa. International Studies of Management \& Organization, 47(3), 276-292. https://doi.org/10.1080/00208825.2017.1318023

Shyam, B. R., Ramachandra Gowda, N. K. (2015). A comparative study of dynamic nature of product life cycle stimulating employee life cycle. Adarsh Journal of Management Research, 8(2), 21-24. https://doi.org/10.21095/ajmr/2015/v8/i2/88210

Smither, L. (2003). Managing employee life cycles to improve labour retention. Leadership and Management in Engineering, 3(1), 19-23. https://doi.org/10.1061/(ASCE)1532-6748(2003)3:1(19)

Soane, E., Truss, C., Alfes, K., Shantz, A., Rees, C., \& Gatenby, M. (2012). Development and application of a new measure of employee engagement: The ISA Engagement Scale. Human Resource Development International, 15(5), 529-547. https://doi.org/10.1080/13678868.2012.726542

Tabassum, R., \& Sahni, D. (2017). Employee life cycle in healthcare industry with reference to Delhi \& NCR: an exploratory study. International Journal of Engineering Science and Computing, 7(3), 5445-5451.

The Work Institute. (2019). Retention Report 2019. https://workinstitute.com/

Thompsen, J. A. (2010). Achieving a triple win: Human capital management of the employee lifecycle (1th ed.). Routledge. https://doi.org/10.4324/9780203875209

Verive, J. M., \& DeLay, N. (2006). Measuring telework ROI: Metrics based on the employee life cycle. World at Work Journal, 15(2), 6-15.

Walker, J. W. (1980). Human resource planning. McGraw-Hill.

Welty, G. (2009). Developing a new employee orientation program for GXP compliance. Journal of GXP Compliance, 13(3) 82-92. 